\title{
Opioid tolerance and physical dependence: Role of spinal neuropeptides, excitatory amino acids and their messengers
}

Khem Jhamandas PhD, Kelly Powell BSc, Remi Quirion PhD, B Milne MD FRCPC

K Jhamandas, K Powell, R Quirion, B Milne. Opioid tolerance and physical dependence: Role of spinal neuropeptides, excitatory amino acids and their messengers.

Pain Res Manage 2000;5(1):25-32.

Chronic opioid treatment results in the development of tolerance and physical dependence. The mechanisms underlying opioid tolerance and/or physical dependence are unclear. Recent studies suggest that opioid receptor or nociceptive, neural network-based adaptations contribute to this phenomenon. At the spinal level, the genesis of tolerance and physical dependence is associated with increased excitatory amino acid activity expressed through $N$-methyl-D-aspartate receptors in the dorsal horn. However, recent evidence also implicates spinal neuropeptide transmitters such as calcitonin gene-related peptide (CGRP) and substance P in the development of opioid tolerance. Long term spinal morphine treatment increases CGRP-like immunostaining in the dorsal horn, and coadministration of morphine with $\mathrm{CGRP}_{8-37}$, a competitive $\mathrm{CGRP}_{1}$ receptor antagonist, prevents this response as well as loss of the analgesic potency. $\mathrm{CGRP}_{8-37}$, like $\mathrm{N}$-methyl-D-aspartate receptor antagonists, has the potential to restore morphine potency in experimental animals who are already tolerant to the opioid agonist. Recent evidence suggests that the effects of excitatory amino acid and neuropeptide receptor activity may be expressed through the generation of messengers such as nitric oxide and prostanoids. Agents that inhibit the synthesis of nitric oxide and prostanoids have the potential to inhibit and reverse spinal opioid tolerance, suggesting that this phenomenon may be expressed through the activity of these mediators. Nociceptive transmission in the dorsal horn of the spinal cord also involves activity of a number of other mediators including morphine modulatory neuropeptides, neuro- peptide FF and neuropeptide SF. The role of these mediators and their relationship with other factors implicated in tolerance remain to be determined.

Key Words: Calcitonin gene-related peptide; Neuropeptide FF; Nitric oxide; N-methyl-D-aspartate; Opioid tolerance; Physical dependence; Prostaglandins; Substance P

\section{Tolérance aux opiacés et dépendance physique : rôle des neuropeptides médullaires, des acides aminés excitateurs et de leurs messagers}

RÉSUMÉ : Les traitements prolongés aux opiacés mènent à la tolérance et à la dépendance physique, et les mécanismes sous-jacents aux deux phénomènes sont nébuleux. Selon des études récentes, les récepteurs opioïdes ou les récepteurs nociceptifs dans le réseau nerveux s'adapteraient à leur nouveau milieu, jouant ainsi un rôle dans l'apparition du problème. La genèse de la tolérance et de la dépendance physique dans la colonne vertébrale est associée à une augmentation de l'activité des acides aminés excitateurs, qui s'exprime par les récepteurs $N$-méthyl-D-aspartate dans la corne supérieure de la moelle. Cependant, des données récentes mettent également en cause les transmetteurs des neuropeptides médullaires comme le peptide lié au gène de la calcitonine (CARP) et la substance P dans l'installation de la tolérance aux opiacés. Le traitement prolongé à la morphine accroît l'immunocoloration aux substances s'apparentant au CARP dans la corne supérieure,

voir page suivante 
et l'administration concomitante de morphine et de $\mathrm{CARP}_{8-37}$, un antagoniste compétitif des récepteurs du $\mathrm{CARP}_{1}$, empêche l'apparition de la réaction ainsi que la perte de l'activité analgésique. Le CARP ${ }_{8-37}$, tout comme les antagonistes des récepteurs $N$-méthyl-D-aspartate, a la capacité de rétablir l'activité de la morphine chez les animaux de laboratoire, rendus tolérants à l'agoniste opioïde. Des données récentes semblent indiquer que les effets de l'activité des récepteurs des neuropeptides et des acides aminés excitateurs s'expriment par la production de messagers comme l'oxyde nitrique et les prostanoïdes. Les substances qui inhibent la synthèse de l'oxyde nitrique et des prostanoïdes ont la capacité d'inhiber et d'inverser la tolérance aux opiacés, ce qui laisse croire que le phénomène se produit par l'intermédiaire de ces médiateurs chimiques. D'autres médiateurs comme les neuropeptides modulateurs de la morphine, les neuropeptides FF et SF, interviennent également dans la transmission de la douleur dans la corne supérieure de la moelle. Le rôle de ces médiateurs et leur lien avec d'autres facteurs dans le phénomène de la tolérance restent à déterminer.
$\mathrm{I}$ is well recognized that morphine and related narcotic analgesics activate opioid receptors in the spinal cord and brain to produce potent analgesia. Chronic treatment with opioids, however, produces tolerance and physical dependence. The development of opioid tolerance and/or dependence can pose a significant barrier to the optimal use of these agents in the treatment of severe pain. In clinical situations, requirements of opioid drugs to relieve severe pain may be increased because of the development of tolerance to the analgesic actions of these drugs or to an increase in the pain stimulus. Because the latter varies considerably in patients, it is difficult to determine the contribution of drug tolerance to the loss of opioid effectiveness. Houde et al (1) demonstrated that tolerance and cross-tolerance develop following chronic opioid treatment. Both opioid tolerance and physical dependence can be produced experimentally following systemic or regional administration of morphine or related opioid agonists. In experimental models involving repeated exposure to an opioid agonist, analgesic tolerance is represented by a rightward shift of the opioid dose-response curve and an increase in the agonist medium effective dose $\left(E D_{50}\right)$ that reflects a reduction in drug potency (Figure 1). Physical dependence is indicated by the appearance of a characteristic withdrawal syndrome that reflects autonomic, somatic and behavioural hyperactivity. It is elicited by the abrupt termination of the drug treatment or by an opioid antagonist challenge delivered during the course of this treatment. Mechanisms contributing to opioid tolerance and/or dependence are poorly understood, but recent evidence derived from experimental models shows that this phenomenon involves a complex interplay among several factors (Figure 2). Thus, chronic opioid treatment may lead to adaptations at the opioid receptor level (2) or at the level of neural networks involved in pain transmission. The network-based adaptation involves altered activity of excitatory amino acids (EAA), neuropeptide transmitters and their intracellular messengers such as nitric oxide and prostaglandins, opioid modulatory factors, and stimulatory actions of opioids (Table 1). Thus, chronic opioid exposure likely produces a latent facilitation of activity in neurons signalling pain. This is a process that augments the presynaptic release or postsynaptic activity of nociceptive transmitters, compromises opioid potency, and gives rise to the sensory, motor and autonomic symptoms of opioid withdrawal. The intracellular messengers nitric oxide and prostaglandins mediate activity of sensory neurotransmitters in the dorsal horn (Figure 2) and appear to play an im-

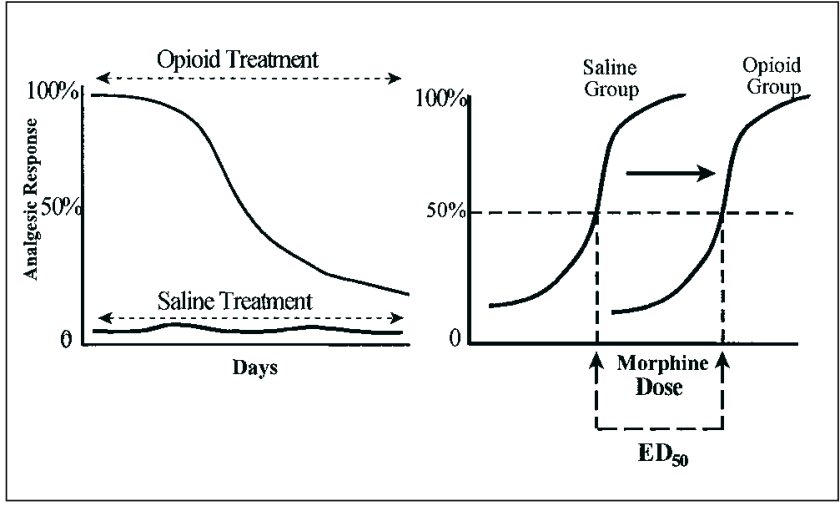

Figure 1) Assessment of experimental opioid tolerance. Chronic opioid drug treatment produces a progressive decline in the antinociceptive effects of the drug. The dose-response curve for the opioid action obtained following this treatment shows a rightward shift, and there is an increase in the medium effective dose (ED50) value

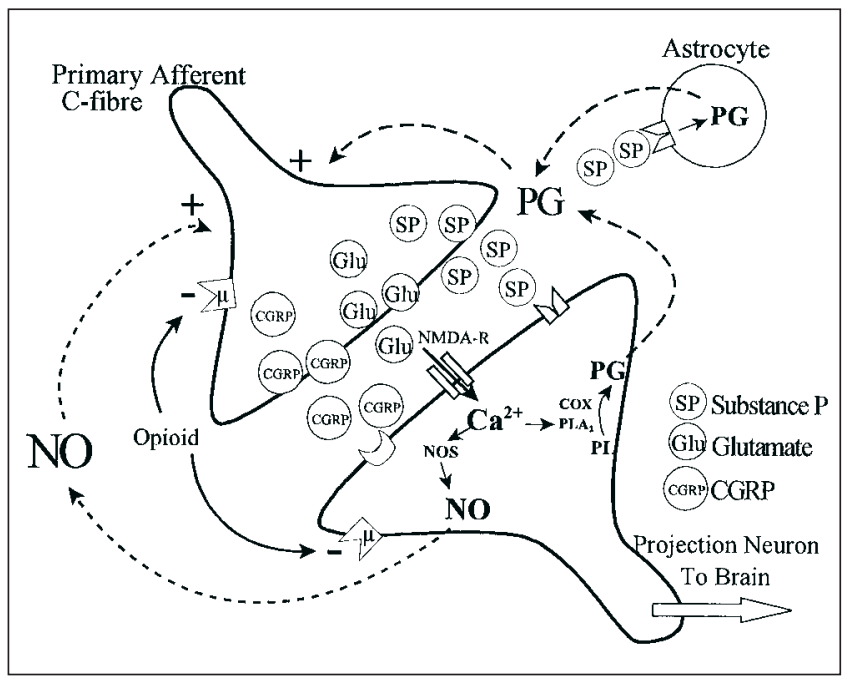

Figure 2) Role of sensory transmitters in pain transmission. Primary afferent c-fibres transmitting noxious stimuli from the periphery to the central nervous system release glutamate (Glu), substance $\mathrm{P}$ (SP) and CGRP (calcitonin gene-related peptide) in the dorsal horn of the spinal cord. Activation of postsynaptic receptors of these transmitters triggers a series of intracellular events that produce second messengers such as prostaglandins (PGs) and nitric oxide (NO). These messengers act on primary afferents to enhance presynaptic transmitter release. Opioid agonists act on both pre- and postsynaptical receptors to inhibit transmitter release and hyperpolarize the neuron, respectively. COX Cyclo-oxygenase; NOS Nitric oxide synthase; PL Phospholipid; PLA Phospholipase 
portant role in the facilitation process underlying the genesis of opioid tolerance and physical dependence. This figure illustrates the roles of some of these factors in opioid tolerance and/or physical dependence at the spinal level.

\section{ROLE OF EXCITATORY AMINO ACID TRANSMITTERS}

At the spinal level, morphine and related agonists produce analgesia by activating the presynaptic opioid receptors located on high threshold primary afferents, and the postsynaptic receptors localized on the projection neurons that are involved in signalling pain at supraspinal levels (3). The activity of presynaptic receptors inhibits the release of neurotransmitters, EAAs (L-glutamate and L-aspartate) and neuropeptides (calcitonin gene-related peptide [CGRP] and substance $\mathrm{P}$ ) that are located in the sensory afferents, while activity of postsynaptic opioid receptors produces hyperpolarization, an effect that resists the excitatory action of pain transmitters on the projection neurons. Given the anatomical and functional relationship between opioids and these sensory transmitters, the development of tolerance at the spinal level is conceived as a cellular or molecular adaptation that produces adjustments in presynaptic transmitter release or receptor activity and that ultimately reduces opioid action. Thus, increasing doses of the opioid may be needed to override such adjustments and produce the original analgesic response. Physical dependence can be viewed as unmasking such adjustments following displacement of the opioid agonist from its receptor sites.

Recent experimental findings indicate that opioid tolerance and physical dependence are cellular adaptations mediated by EAA transmitter activity, expressed through a subclass of receptors, the $N$-methyl-D-aspartate (NMDA) receptor. This concept is supported by the results of pharmacological experiments demonstrating that NMDA receptor blockade effectively inhibits the development of opioid tolerance and/or dependence (4-7). Sites of the central nervous system at which NMDA receptor activity produces adaptations to chronic opioid treatment are unclear, but the dorsal horn may be an important locus because both opioid and NMDA receptors are present in this area, and their activity produces opposing actions of analgesia and hyperalgesia.

Evidence obtained from experimental models of morphine tolerance and produced by repeated intrathecal morphine injections or continuous opioid delivery to the spinal cord, suggests that increased EAA activity contributes to the decline of the analgesic response. Spinal administration of the noncompetitive NMDA receptor antagonist MK 801 reduces the development of tolerance to the thermal analgesia produced by repeated morphine injections (7) or continuous infusion of the opioid into the intrathecal space (4). Additionally, MK 801 treatment attenuates signs of opioid withdrawal, including hyperalgesia, precipitated by a challenge with the opioid antagonist naloxone (4). These experiments suggest that chronic morphine treatment induces a compensatory increase in spinal NMDA receptor activity that inhibits morphine action and is unmasked by the removal of
TABLE 1

Diverse views of opioid tolerance

\begin{tabular}{lc}
\hline $\begin{array}{l}\text { Opioid receptor-based } \\
\text { adaptation }\end{array}$ & Network-based adaptation \\
\hline $\begin{array}{l}\text { Downregulation of receptors } \\
\text { Reduced inhibitory G protein } \\
(\mathrm{Gi} / \mathrm{Go}) \text { activity }\end{array}$ & $\begin{array}{c}\text { Increase in activity of nociceptive } \\
\text { transmitters (Substance P, } \\
\text { calcitonin gene-related } \\
\text { Predominance of stimulatory } \\
\text { mode of opioid receptor }\end{array}$ \\
& peptide, L-glutamate/aspartate) \\
& and their messengers (nitric \\
oxide, prostaglandins) & Decreased activity of \\
antinociceptive \\
transmitters/modulators \\
(adenosine, neuropeptide FF, \\
galanin) \\
Increased activity of endogenous \\
opioid antagonists \\
(cholecystokinin, \\
beta-endorphin ${ }_{1-27}$ ) \\
\hline
\end{tabular}

morphine from its receptor sites. Stimulation of NMDA receptors in the dorsal horn is known to elicit hyperalgesia (8), and an increase in activity of these receptors during long term morphine treatment could physiologically antagonize the analgesic response produced by the opioid agonist. The NMDA hyperalgesia, exposed during drug withdrawal, contributes to the pain behaviour and other symptoms associated with this state. The nature of mechanisms that produce an increase in NMDA activity during long term morphine treatment is not clear. Spinal microdialysis experiments on unanesthetized animals (9) have not revealed increased baseline release of L-glutamate or L-aspartate levels during chronic infusions of intrathecal morphine. However, a significant increase in the spinal L-glutamate and L-aspartate levels during the naloxone-induced morphine withdrawal has been observed. The time course of this release response parallels that of the behavioural response, and both are significantly reduced in animals treated with NMDA receptor antagonists (9). Thus, adjustments in EAA transmitter release may occur during chronic morphine exposure and may become apparent after drug removal. NMDA receptor activity contributes to the induction of tolerance, and appears to contribute to its expression and maintenance. In animals rendered tolerant to systemic morphine, administration of NMDA receptor antagonists can produce a recovery of the analgesic response $(5,10,11)$. Recently, it was demonstrated that ketamine, a noncompetitive NMDA antagonist, restores opioid potency in animals made tolerant to morphine by repeated intrathecal injections (5). These and other observations suggest that EAA transmitter activity expressed through spinal NMDA receptors makes a very significant contribution to the genesis of opioid tolerance and physical dependence. The role of the supraspinal EAA mechanisms in this respect is largely unknown. The significance of non-NMDA receptors in the genesis of tolerance and physical dependence at the spinal level is also unclear, although recent studies involving systemic morphine and use of group I, II and III antagonists have 
implicated metabotropic glutamate receptors in the development of physical dependence $(12,13)$.

\section{ROLE OF NEUROPEPTIDE TRANSMITTERS}

CGRP and substance P exist in primary afferents that transmit nociceptive signals from the periphery to the spinal cord. These peptides can coexist with each other (14) and Lglutamate, and act on distinct receptors, and their release is modulated by opioid agonists (15). Thus, like L-glutamate and L-aspartate, these neuropeptide transmitters are considered physiological antagonists of opioid activity. In view of the colocalization of these neuropeptides with EAA transmitters and the involvement of EAA activity in chronic effects of opioid drugs, the role of sensory neuropeptides in the genesis of opioid tolerance and physical dependence merits consideration. Thus, we have undertaken studies to explore their role in models of spinal opioid tolerance, and the results reveal that the activity of these neuropeptide pain transmitters indeed contributes to this phenomenon.

In experiments involving continuous intrathecal infusions of morphine via catheters linked to osmotic minipumps, it was demonstrated that the CGRP-like immunostaining in superficial, but not deep, layers of the dorsal horn is significantly increased. However, CGRP receptor binding levels are reduced, possibly in response to the augmented peptide release $(16,17)$. In this model, the changes in CGRP markers were peptide specific, could be produced by both mu and delta opioid receptor activity, and coincided with a decline of morphine antinociception. Importantly, co-administration of $\mathrm{CGRP}_{8-37}$, a competitive CGRP receptor antagonist, produced a dose-dependent inhibition of tolerance to intrathecal morphine in the tail flick and paw pressure tests (18). The peptide antagonist thus maintained the thermal and mechanical antinociception produced by morphine, and prevented the decline of the morphine $\mathrm{ED}_{50}$ value resulting from chronic drug infusion. The effects of $\mathrm{CGRP}_{8-37}$ on tolerance occurred at doses that did not modify the acute antinociceptive actions of morphine in both tests. Interestingly, the antagonist also prevented the increase in CGRP-like immunostaining and the decrease in CGRP receptor binding levels produced by chronic morphine (18). Collectively, the results of these studies offer strong evidence that augmentation of spinal CGRP contributes to the development of morphine tolerance.

Recently, we examined whether the activity of spinal CGRP has a role in the maintenance of morphine tolerance. CGRP $_{8-37}$ was administered to animals showing loss of morphine antinociception following repeated drug morphine injections over a five-day period. When morphine was combined with the CGRP receptor antagonist and administered over the subsequent five-day period, the response to morphine was partially recoverable (19). This recovery was reflected in potency values for the acute action of morphine determined at the end of the treatment period. The $\mathrm{ED}_{50}$ values of acute morphine in the animal group receiving $\mathrm{CGRP}_{8-37}$ with morphine returned toward the control value. Interestingly, $\mathrm{CGRP}_{8-37}$ treatment partially reversed the in- crease in CGRP-like immunostaining resulting from chronic opioid treatment. These observations suggest that the activity of the primary afferent neuropeptide CGRP also modulates the expression of spinal opioid tolerance. The cellular or molecular mechanisms by which CGRP influences opioid tolerance are not clear. In different tissue preparations, CGRP receptor activity produces activation of adenylyl cyclase and increases translocation of calcium (20), effects that are opposite to those produced by opioid activity. Thus, CGRP activity may interfere with opioid activity at the signal transduction level and impair the analgesic effects of morphine. The role of CGRP in physical dependence remains to be explored.

Although CGRP clearly modulates spinal morphine tolerance, pharmacological experiments with the antagonist showed that neither the blockade nor reversal of morphine tolerance was complete. This suggested involvement of additional factors in tolerance; therefore, we focused our attention on substance $\mathrm{P}$, which exists in primary afferents and in some neurons is colocalized with CGRP (14). Previous studies $(21,22)$ have implicated substance $P$ in morphine withdrawal, but its role in tolerance is obscure. In our previous experiments (17) on the continuous intrathecal infusion model of morphine tolerance, no significant change in the substance P-like immunostaining was apparent. However, in recent experiments, we have re-examined this using the repeated morphine injection model in which the drug is administered once daily. In this model, substance P-like immunostaining in the dorsal horn was found to increase. To determine whether this increase contributes to morphine tolerance, the potential of a nonpeptide, substance $\mathrm{P}$ receptor antagonist (SR140333) to influence this phenomenon was evaluated using the approaches employed in our preceding work with the CGRP receptor antagonist. Combination of morphine with the antagonist significantly attenuated the development of tolerance to morphine in the tail flick and paw pressure tests. This effect was seen at doses that did not modify the acute effects of morphine. In addition, when administered to tolerant animals, this antagonist restored the antinociceptive action of morphine to almost original levels (unpublished data). These observations thus suggest that spinal substance $\mathrm{P}$ and its receptors also play a role in the phenomenon of tolerance. The potential involvement of substance $\mathrm{P}$ in the genesis of physical dependence at the spinal level is under study in our laboratory.

The finding that activity of sensory neuropeptides contributes to the genesis of opioid tolerance is compatible with the observations implicating EAA transmitter activity in this phenomenon. Both neuropeptides are colocalized with glutamate in primary afferents, and they interact functionally and reciprocally with EAA transmitters. In the spinal cord, CGRP and substance $\mathrm{P}$ have been demonstrated to promote release of glutamate (23) and to augment NMDA receptor activity (24). Activation of presynaptic NMDA receptors localized on terminals of nociceptive afferents have been reported to stimulate the release of substance P $(25,26)$. Additionally, EAA and substance $\mathrm{P}$ activity in the spinal cord generate 
prostanoids, which mediate hyperalgesia (8). Thus, it is likely that the activity of neuropeptides influences opioid tolerance, and has the potential to affect physical dependence by influencing presynaptic or postsynaptic activity of EAA receptors mediating this phenomenon. In view of the anatomical and functional links between these sensory transmitters, it is concluded that their interactive influence produces spinal opioid analgesic tolerance and physical dependence.

\section{ROLE OF MESSENGER MOLECULES}

There is compelling evidence that nitric oxide, generated via the activity of nitric oxide synthase (NOS), plays an intermediary role in the expression of responses resulting from the stimulation of NMDA receptors (27-29). Thus, there has been interest in the idea that opioid tolerance and/or physical dependence, an NMDA receptor-mediated phenomenon, is expressed through the formation of nitric oxide. Agents that produce nitric oxide have been found to increase the release of neuropeptides from spinal cord tissue (30), and in other models, nitric oxide has been implicated in the release of Lglutamate. Recently, inhibitors of NOS have been reported to reduce the development of tolerance produced by systemic morphine $(31,32)$. However, these inhibitors minimally influence the tolerance resulting from continuous spinal infusion of morphine (33), thus raising doubts about the involvement of nitric oxide in spinal morphine tolerance. It has been suggested that neuronal NOS forms in the spinal and supraspinal levels may differ and activity of the former may facilitate morphine action (34). In view of this, it is likely that, at the spinal level, pain behaviours such as hyperalgesia elicited by the spinal NMDA receptor activity are expressed through alternate intermediaries. Recent evidence suggests that the activation of spinal NMDA receptors, and interestingly substance $\mathrm{P}$ receptors, elicits hyperalgesia that is sensitive to inhibitors of the enzyme cyclo-oxygenase (COX), which catalyzes the production of prostanoids (8). This and other evidence support the notion that in the dorsal horn prostanoids serve as intermediaries in responses expressed through NMDA or substance P receptor activity. Considering this role of prostanoids, we examined their significance in the development and expression of spinal morphine tolerance (35). Two COX inhibitors, ketorolac (Novopharm Ltd, Toronto, Ontario) and ibuprofen, were tested for their ability to influence tolerance to the thermal and mechanical antinociceptive effects of spinal morphine. In parallel experiments, the effect of these agents was compared with that of the NOS inhibitor, $N^{\mathrm{w}}$-nitro-L-arginine methyl ester (L-NAME). Under the conditions employed in these experiments, none of the agents tested influenced the baseline responses or augmented the acute actions of morphine in the two nociception tests. However, when coinjected with morphine, both ketorolac and ibuprofen effectively attenuated the development of tolerance to repeated intrathecal morphine. The stereoselective action of ibuprofen in this respect suggested that the inhibition of COX activity was responsible for the antitolerance effect. In animals with established spinal tolerance, administration of ketorolac with morphine also significantly restored the potency of acute morphine. In parallel experiments, L-NAME also mimicked the effects of COX inhibitors but showed weaker activity. This suggests that products of COX activity play a more prominent role in the development and expression of tolerance to spinal morphine. Prostanoids generated in response to repeated morphine exposure likely oppose the inhibitory action of this drug on high threshold primary afferents. In the spinal cord, prostanoid receptors have been localized on these afferents (36), and their activity produces biochemical and physiological responses that are opposite to those produced by opioids (35). Thus, physiologically, prostanoids may antagonize the depression of primary afferent transmitter release by opioids and thus reduce their analgesic activity. The mechanism by which prostanoid activity may be generated in response to morphine is not known. However, a study on cells transfected with opioid receptor mRNA showed that acute exposure of these cells to opioid agonists produced a calcium-dependent release of arachidonic acid, the precursor of prostanoids (37). Thus, it is likely that this also occurs in the dorsal horn. The production of prostanoids in response to repeated morphine would reinforce the function of primary afferents releasing glutamate, substance $\mathrm{P}$ and CGRP and compromise opioid analgesia. Additional studies need to investigate the role of prostanoids in opioid tolerance. However, in view of the observed effects of COX inhibitors on experimental tolerance, these inhibitors may be useful in modulating clinical tolerance to opioid drug treatment. The role of prostanoids in the genesis of physical dependence is under exploration.

\section{ROLE OF OPIOID MODULATORY PEPTIDES}

Several opioid (beta-endorphin ${ }_{1-27}$, dynorphin and methionine-enkephalin) and nonopioid peptides (alpha-melanocyte-stimulating hormone [alpha-MSH], tyrosine-melanocyte-stimulating hormone release-inhibiting factor [TyrMIF], thyrotropin-releasing hormone [TRH], cholecystokinin octapeptide [CCK-8] and neuropeptide FF [NPFF], nociceptin) have been reported to inhibit morphine analgesia, augment tolerance and/or precipitate withdrawal (38). Although no agent has emerged as an endogenous naloxonelike, anti-opioid factor, it has been hypothesized that augmented activity of one or more of these peptides may contribute to the development of tolerance and physical dependence. Recent interest in this area has focused on NPFF and related peptides that were designated as anti-opioids in earlier studies. However, in subsequent studies NPFF and its analogues were found to exert pro-opioid effects. Thus, these peptides can be considered as opioid modulatory peptides.

In 1985, Yang et al (39) isolated an octapeptide, NPFF, (Figure 3) and an octadecapeptide, Ala-Gly-Glu-Gly-LeuSer-Ser-Pro-Phe-Try-Ser-Leu-Ala-Ala-Pro-Gln-Arg-Phe-N $\mathrm{H}_{2}(\mathrm{AF})$, from the bovine brain and reported that intraventricular administration of these peptides inhibited morphine analgesia. Subsequently, Yang and Martin (40) reported isolation of another octapeptide (neuropeptide SF [NPSF]), and Perry et al (41) cloned a human gene coding for two peptides 


\section{NPFF $=$ F-L-F-QP \\ NPSF $=$ S-L-A-A P-Q-R-F-NH}

Figure 3) The structure of morphine modulatory peptides derived from a neuropeptide FF (NPFF) precursor. NPSF Neuropeptide SF

structurally related to NPFF and AF. NPFF immunoreactivity is localized in the superficial, dorsal spinal cord; medullary regions (nucleus tractus solitarius, parabrachial nucleus, area postrema) and areas of the hypothalamus involved in pain transmission; and autonomic and endocrine regulation (42). Receptor autoradiographic studies have revealed high density NPFF binding sites in the superficial dorsal horn and in caudal brain areas; a pattern overlapping opioid receptor distribution $(43,44)$. Spinal NPFF immunoreactivity is localized in intrinsic neurons of the dorsal horn and a portion of NPFF binding sites, like the opioid sites, are located on terminals of high threshold primary afferents (45). NPFF binding is not significantly influenced by mu, delta or kappa receptor ligands (43) but is regulated by GTP (guanosine 5'triphosphate) and cations (46). NPFF shows a calcium-dependent release in response to depolarizing stimuli, including the application of a calcium-dependent release of NPFF from the isolated spinal cord (47). This release is also stimulated by NMDA and/or low concentrations of morphine $(48,49)$.

Pharmacological studies involving intracerebral administration of NPFF or its synthetic analogues with greater metabolic stability $(50,51)$ have reported anti-opioid effects, including precipitation of withdrawal symptoms in morphine-dependent rats $(52,53)$. Considering the documented anti-opioid profile of NPFF, we examined whether NPFF immunoreactive neurons in the brain are activated during the naloxone precipitated withdrawal in animals given chronic infusions of intracerebral morphine. However, this activation could not be demonstrated by using combined c-fos and NPFF immunohistochemistry, although such activation was apparent in a model of hypotensive stress (54). Similarly, administration of an NPFF analogue to morphine-dependent animals failed to precipitate symptoms of opioid withdrawal or induce c-fos expression in different brain areas (55). Thus, the role of brain NPFF in the production of opioid withdrawal syndrome remains unclear.

NPFF-related peptides can also exert pro-opioid actions, especially at the level of the spinal cord. We found that intrathecal injections of NPFF or the molluscan cardiotonic peptide, Phe-Met-Arg-Phe- $\mathrm{NH}_{2}$ (FMRFamide), produced a sustained and reversible antinociception that was partially attenuated by intrathecal naloxone (56). Subanalgesic doses of NPFF greatly augmented the action of morphine on thermal

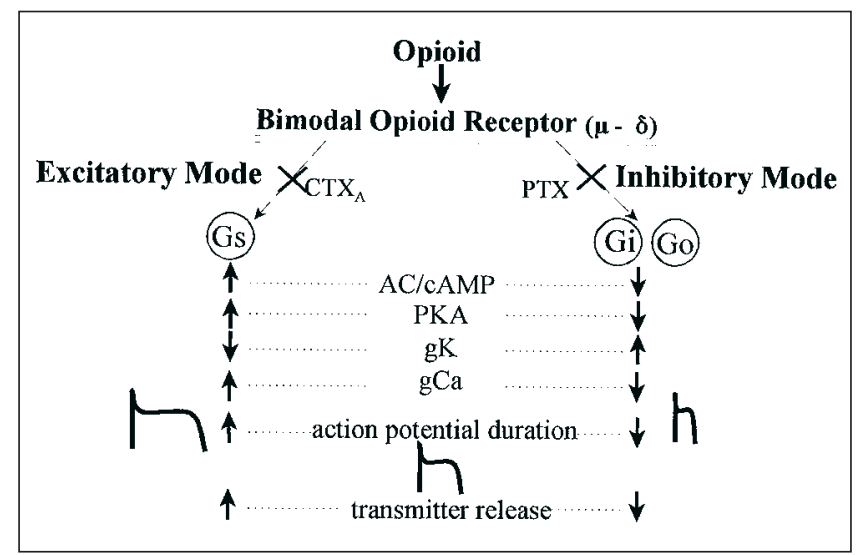

Figure 4) Bimodal modulation of mu-opioid receptor activity. Opioid receptor activation produces opposing intracellular signalling events that produce excitatory responses. High doses of opioids $(\mu \mathrm{M})$ initiate the inhibitory intracellular signalling events that produce analgesia through $G$ protein $\left(\mathrm{G}_{\mathrm{i} / \mathrm{o}}\right)$ coupled to adenylyl cyclase. Low doses ( $\mathrm{nM}$ ) initiate excitatory intracellular signalling events through $\mathrm{G}$ protein $\left(\mathrm{G}_{\mathrm{s}}\right)$ coupled to adenylyl cyclase. Predominance of the excitatory mode contributes to the development of tolerance and physical dependence. AC AdenyIyl cyclase; CTX A Cholera toxin; gCa Calcium conductance; gK Potassium conductance; PKA Protein kinase A; PTX Pertussis toxin. Data from reference 62

and mechanical nociception. In subsequent experiments, NPFF analogues exhibiting a high affinity for the NPFF binding sites and resistance to degradation (45) were found to produce analgesia that could be partially reduced by intrathecal injection of mu or delta receptor-selective antagonists. These analogues also remarkably augmented the spinal antinociception produced by mu or delta opioid receptor agonists. The analgesia produced by these agents was apparent $24 \mathrm{~h}$ postadministration; animals recovered fully from this effect. The mechanisms underlying these modulatory effects of NPFF on spinal opioids are unclear; however, experiments on the dorsal root ganglia neurons suggest that NPFF may act by influencing the translocation of calcium (53). Recent experiments demonstrated that NPFF results in spinal opioid release (57). If these opioid facilitatory actions of NPFF and related neuropeptides are considered, it is likely that the decline in analgesia seen following chronic morphine treatment represents a loss of the positive modulatory action of NPFF and similar peptides. However, clear evidence of this deficit is lacking. This notwithstanding, we have recently observed that the NPFF-related peptide NPSF augments morphine antinociception in animals rendered tolerant to the action of intrathecal morphine (unpublished data). Thus, peptides such as NPFF may have a role in the genesis of tolerance and possibly physical dependence at the spinal level; however additional studies are needed to clarify this role.

\section{ROLE OF STIMULATORY ACTIONS OF OPIOIDS}

Opioid facilitatory actions of NPFF and its analogues that have been observed appear to be inconsistent with the original designation of these peptides as anti-opioids. However, 
pharmacological studies in mice have demonstrated that ultra-low doses of the established opioid antagonists such as naloxone and naltrexone can enhance the analgesic action of morphine, and attenuate development of tolerance and/or physical dependence (58). Crain and Shen (59), and Shen et al (60), on the basis of behavioural studies in mice and electrophysiological studies on the dorsal root ganglia, proposed a model in which the opioid receptor is coupled bimodally to intracellular messengers (Figure 4). In this model, ultra-low concentrations of morphine produce an excitatory response that is antagonized by similar concentrations of an opioid antagonist. Conversely, high concentrations of morphine produce an inhibitory response that is blocked by similar concentrations of the antagonist. Tolerance and physical dependence are conceived as predominance of the excitatory mode of the opioid receptor. The facilitation of morphine analgesia that we have observed with NPFF, therefore, may represent a blockade of the excitatory mode of the opioid receptor. Thus, NPFF and related modulatory peptides may play a role in the genesis of spinal opioid tolerant and/or de-

\section{REFERENCES}

1. Houde RW, Wallenstein SL, Beaver, WT. Evaluation of analgesics in patients with cancer pain. In: Lasagna L, ed. International Encyclopedia of Pharmacology and Therapeutics. Oxford: Pergamon, 1966;1:59-98.

2. Nestler EJ, Alreja M, Aghajanian GK. Molecular and cellular mechanisms of opiate action: studies in the rat locus coeruleus. Brain Res Bull 1994;35:521-8.

3. Yaksh TL. Opioid receptor systems and the endorphins: a review of their spinal organization. J Neurosurg 1987;67:157-76.

4. Dunbar S, Yaksh TL. Concurrent spinal infusion of MK801 blocks spinal tolerance and dependence induced by chronic intrathecal morphine in the rat. Anesthesiology 1996;84:1177-88.

5. Shimoyama N, Shimoyama M, Inturrisi CE, Elliott KJ. Ketamine attenuates and reverses morphine tolerance in rodents. Anesthesiology 1996;85:1357-66.

6. Trujillo KA, Akil H. Inhibition of morphine tolerance and dependence by the NMDA receptor antagonist MK-801. Science 1991;251:85-7.

7. Mao J, Price DD, Mayer DJ. Thermal hyperalgesia in association with the development of morphine tolerance in rats: roles of excitatory amino acid receptors and protein kinase C. J Neurosci 1994;14:2301-12.

8. Malmberg AB, Yaksh TL. Hyperalgesia mediated by spinal glutamate or substance $\mathrm{P}$ receptor blocked by spinal cyclooxygenase inhibition. Science 1992;257:1276-9.

9. Jhamandas KH, Marsala M, Ibuki T, Yaksh TL. Spinal amino acid release and precipitated withdrawal in rats chronically infused with spinal morphine. J Neurosci 1996;16:2758-66.

10. Elliott K, Hynansky A, Inturrisi CE. Dextromethorphan attenuates and reverses analgesic tolerance to morphine. Pain 1994;59:361-8.

11. Tiseo PJ, Inturrisi CE. Attenuation and reversal of morphine tolerance by the competitive $N$-methyl-D-aspartate receptor antagonist, LY274614. J Pharmacol Exp Ther 1993;264:1090-6.

12. Fundytus ME, Coderre TJ. Effect of activity at metabotropic, as well as ionotropic (NMDA), glutamate receptors on morphine dependence. Br J Pharmacol 1994;113:1215-20.

13. Fundytus ME, Ritchie J, Coderre TJ. Attenuation of morphine withdrawal symptoms by subtype-selective metabotropic glutamate receptor antagonists. Br J Pharmacol 1997;120:1015-20.

14. Wiesenfeld-Hallin Z, Hokfelt T, Lundberg JM, et al. Immunoreactive calcitonin gene-related peptide and substance $\mathrm{P}$ coexist in sensory neurons to the spinal cord and interact in spinal behavioural responses of the rat. Neurosci Lett 1984;52:199-204. pendent states, and experiments are in progress to investigate this possibility.

The development of tolerance and dependence at the spinal level appears to involve multiple mechanisms. The phenomena of tolerance and dependence may have independent (61) as well as shared mechanisms (6). It is significant, however, that the activity of sensory transmitters and their messengers eliciting pain behaviours at the spinal level also contributes to the genesis of opioid tolerance at this level. The challenge in future studies is to determine how different transmitter and receptor-based mechanisms are related to each other and how their interplay leads to the phenomenon of opioid tolerance and physical dependence.

ACKNOWLEDGEMENTS: Supported by the Medical Research Council of Canada. KJP was supported by Ferring. Travel support from the Ontario-Quebec Exchange program is gratefully acknowledged.

15. Pohl M, Lombard MC, Bourgoin S, et al. Opioid control of the in vitro release of calcitonin gene-related peptide from primary afferent fibres projecting in the rat cervical cord. Neuropeptides 1989;14:151-9.

16. Menard DP, van Rossum D, Kar S, Quirion R. Alteration of calcitonin gene related peptide and its receptor binding sites during the development of tolerance to mu and delta opioids. Can J Physiol Pharmacol 1995;73:1089-95.

17. Menard DP, van Rossum D, Kar S, Jolicoeur FB, Jhamandas K, Quirion R. Tolerance to the antinociceptive properties of morphine in the rat spinal cord: alteration of calcitonin gene-related peptide-like immunostaining and receptor binding sites. J Pharmacol Exp Ther 1995;273:887-94.

18. Menard DP, van Rossum D, Kar S, et al. A calcitonin gene-related peptide receptor antagonist prevents the development of tolerance to spinal morphine analgesia. J Neurosci 1996;16:2342-51.

19. Powell KJ, Ma W, Quirion R, Jhamandas K. Calcitonin Gene-Related Peptide Receptor Antagonist Reverses Spinal Morphine Tolerance. Soc Neurosci 1999;25:181.

20. van Rossum D, Hanisch UK, Quirion R. Neuroanatomical localization, pharmacological characterization and functions of CGRP, related peptides and their receptors. Neurosci Biobehav Rev 1997;21:649-78.

21. Johnston PA, Chahl LA. Tachykinin antagonists inhibit the morphine withdrawal response in guinea-pigs, Naunyn Schmiedebergs Arch Pharmacol 1991;343:283-8.

22. Kreeger JS, Larson AA. Substance P-(1-7), a substance P metabolite, inhibits withdrawal jumping in morphine-dependent mice. Eur J Pharmacol 1993;238:111-5.

23. Kangrga I, Larew JS, Randic M. The effects of substance P and calcitonin gene-related peptide on the efflux of endogenous glutamate and aspartate from the rat spinal dorsal horn in vitro. Neurosci Lett 1990;108:155-60.

24. Murase K, Ryu PD, Randic M. Excitatory and inhibitory amino acids and peptide-induced responses in acutely isolated rat spinal dorsal horn neurons. Neurosci Lett 1989;103:56-63.

25. Liu H, Wang H, Sheng M, Jan LY, Jan YN, Basbaum AI. Evidence for presynaptic $N$-methyl-D-aspartate autoreceptors in the spinal cord dorsal horn, Proc Natl Acad Sci USA 1994;91:8383-7.

26. Liu H, Mantyh PW, Basbaum AI. NMDA-receptor regulation of substance $\mathrm{P}$ release from primary afferent nociceptors. Nature 1997;386:721-4.

27. Garthwaite J. Glutamate, nitric oxide and cell-cell signalling in the nervous system. Trends Neurosci 1991;14:60-7. 
28. Meller ST, Gebhart GF. Nitric oxide (NO) and nociceptive processing in the spinal cord. Pain 1993;52:127-36.

29. Malmberg AB, Yaksh TL. Spinal nitric oxide synthesis inhibition blocks NMDA-induced thermal hyperalgesia and produces antinociception in the formalin test in rats. Pain 1993;54:291-300.

30. Garry MG, Richardson JD, Hargreaves KM. Sodium nitroprusside evokes the release of immunoreactive calcitonin gene-related peptide and substance $\mathrm{P}$ from dorsal horn slices via nitric oxide-dependent and nitric oxide-independent mechanisms. J Neurosci 1994;14:4329-37.

31. Kolesnikov YA, Pick CG, Pasternak GW. NG-nitro-L-arginine prevents morphine tolerance. Eur J Pharmacol 1992;221:399-400.

32. Kolesnikov YA, Pick CG, Ciszewska G, Pasternak GW. Blockade of tolerance to morphine but not to kappa opioids by a nitric oxide synthase inhibitor. Proc Natl Acad Sci USA 1993;90:5162-6.

33. Dunbar S, Yaksh TL. Effect of spinal infusion of L-NAME, a nitric oxide synthase inhibitor, on spinal tolerance and dependence induced by chronic intrathecal morphine in the rat. Neurosci Lett 1996;207:33-6.

34. Kolesnikov YA, Pan YX, Babey AM, Jain S, Wilson R, Pasternak GW. Functionally differentiating two neuronal nitric oxide synthase isoforms through antisense mapping: evidence for opposing NO actions on morphine analgesia and tolerance. Proc Natl Acad Sci USA 1997;94:8220-5.

35. Powell KJ, Hosokawa A, Bell A, et al. Comparative effects of cyclo-oxygenase and nitric oxide synthase inhibition on the development and reversal of spinal opioid tolerance. Br J Pharmacol 1999;127:631-44.

36. Matsumura K, Watanabe Y, Imai-Matsumura K, Connolly M, Koyama Y, Onoe H. Mapping of prostaglandin E2 binding sites in rat brain using quantitative autoradiography. Brain Res 1992:581:292-8.

37. Fukuda K, Kato S, Morikawa H, Shoda T, Mori K. Functional coupling of the delta-, mu-, and kappa-opioid receptors to mitogen-activated protein kinase and arachidonate release in Chinese hamster ovary cells. J Neurochem 1996;67:1309-16.

38. Rothman R. A review of the role of anti-opioid peptides in morphine tolerance and dependence. Synapse 1992;12:129-38.

39. Yang HY, Fratta W, Majane EA, Costa E. Isolation, sequencing, synthesis, and pharmacological characterization of two brain neuropeptides that modulate the action of morphine. Proc Natl Acad Sci USA 1985;82:7757-61.

40. Yang H-YT, Martin BM. Isolation and characterization of a neuropeptide FF-like peptide from brain and spinal cord of rat. Soc Neurosci 1995;21:760.

41. Perry SJ, Yi-Kung HE, Cronk D, et al. A human gene encoding morphine modulating peptides related to NPFF and FMRFamide. FEBS Lett 1997;409:426-30.

42. Kivipelto L, Majane EA, Yang HY, Panula P. Immunohistochemical distribution and partial characterization of FLFQPQRFamidelike peptides in the central nervous system of rats. J Compar Neurol 1989;286:269-87.

43. Allard M, Geoffre S, Legendre P, Vincent JD, Simonnet G. Characterization of rat spinal cord receptors to FLFQPQRFamide, a mammalian morphine modulating peptide: a binding study. Brain Res 1989;500:169-76.

44. Allard M, Zajac JM, Simonnet G. Autoradiographic distribution of receptors to FLFQPQRFamide, a morphine-modulating peptide, in rat central nervous system. Neuroscience 1992;49:101-16.
45. Gouarderes C, Kar S, Zajac JM. Presence of neuropeptide FF receptors on primary afferent fibres of the rat spinal cord. Neuroscience 1996;74:21-7.

46. Payza K, Yang HY. Modulation of neuropeptide FF receptors by guanine nucleotides and cations in membranes of rat brain and spinal cord. J Neurochem 1993;60:1894-9.

47. Zhu J, Jhamandas K, Yang HY. Release of neuropeptide FF (FLFQPQRF-NH2) from rat spinal cord. Brain Res 1992;592:326-32.

48. Devillers JP, Simonnet G. Modulation of neuropeptide FF release from rat spinal cord slices by glutamate. Involvement of NMDA receptors. Eur J Pharmacol 1994;271:185-92.

49. Devillers JP, Boisserie F, Laulin JP, Larcher A, Simonnet G. Simultaneous activation of spinal antiopioid system (neuropeptide FF) and pain facilitatory circuitry by stimulation of opioid receptors in rats. Brain Res 1995;700:173-81.

50. Gicquel S, Mazarguil H, Allard M, Simonnet G, Zajac JM. Analogues of F8Famide resistant to degradation, with high affinity and in vivo effects. Eur J Pharmacol 1992;222:61-7.

51. Million M, Fioramonti J, Gicquel S, Zajac JM, Bueno L. Comparative action of Phe-Leu-Phe-Gln-Pro-Gln-Arg-Phe-NH2 analogs on intestinal motility and nociception in rats. J Pharmacol Exp Ther 1993:265:96-102.

52. Malin DH, Lake JR, Hammond MV, et al. FMRF-NH2-like mammalian octapeptide: possible role in opiate dependence and abstinence. Peptides 1990;11:969-72.

53. Roumy M, Zajac J-M. Neuropeptide FF, pain and analgesia. Eur J Pharmacol 1998;345:1-11.

54. Jhamandas JH, Harris KH, Petrov T, Yang HY, Jhamandas KH. Activation of neuropeptide FF neurons in the brainstem nucleus tractus solitarius following cardiovascular challenge and opiate withdrawal. J Comp Neurol 1998;402:210-21.

55. Jhamandas KH, Harris KH, Sutak M, Jhamandas JH. Effects of naloxone and neuropeptide FF on the expression of c-Fos in the brain of morphine-dependent rats. Soc Neurosci 1995;20:1849.

56. Gouarderes C, Sutak M, Zajac JM, Jhamandas K. Antinociceptive effects of intrathecally administered F8Famide and FMRFamide in the rat. Eur J Pharmacol 1993;237:73-81.

57. Ballet S, Mauborgne A, Gouarderes C, et al. The neuropeptide FF analogue, 1DME, enhances in vivo met-enkephalin release from the rat spinal cord. Neuropharmacology 1999;38:1317-24.

58. Shen KF, Crain SM. Ultra-low doses of naltrexone or etorphine increase morphine's antinociceptive potency and attenuate tolerance/dependence in mice. Brain Res 1997;757:176-90.

59. Crain SM, Shen KF. Opioids can evoke direct receptor-mediated excitatory effects on sensory neurons. Trends Pharmacol Sci 1990;11:77-81.

60. Shen KF, Crain SM. Dual opioid modulation of the action potential duration of mouse dorsal root ganglion neurons in culture. Brain Res 1989;491:227-42.

61. Schulz R, Wuster M, Krenss H, Herz A. Selective development of tolerance without dependence in multiple opioid receptors of mouse vas deferens. Nature 1980;285:242-3

62. Crain SM, Shen KF, Ultra-low concentrations of naloxone selectively antagonize excitatory effects of morphine on sensory neurons, thereby increasing itsantinociceptive potency and attenuating tolerance/dependence during chronic cotreatment. Proc Natl Acad Sci USA 1995;92:10540-4. 


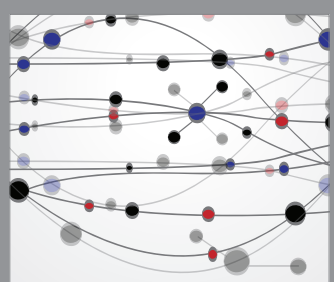

The Scientific World Journal
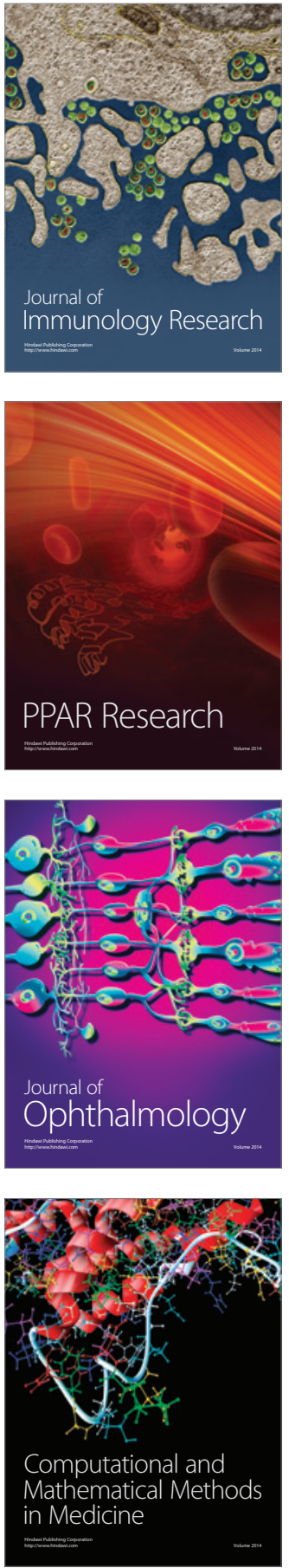

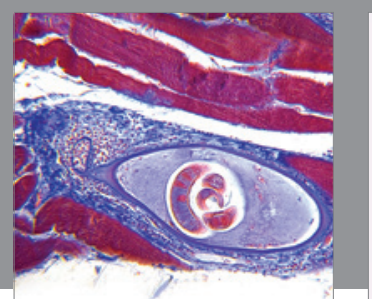

Gastroenterology Research and Practice

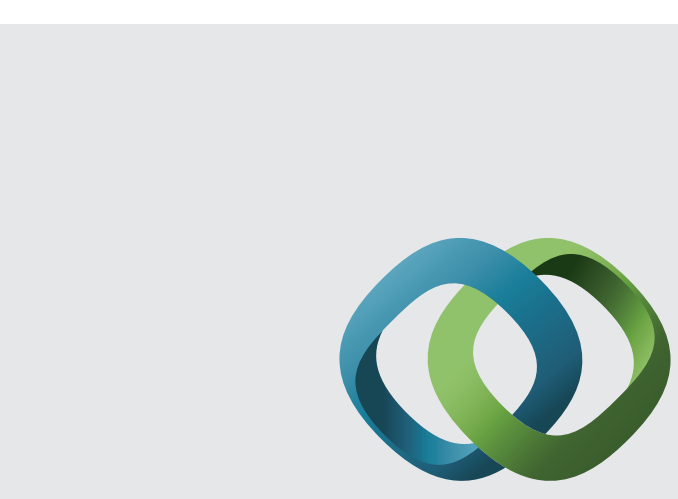

\section{Hindawi}

Submit your manuscripts at

http://www.hindawi.com
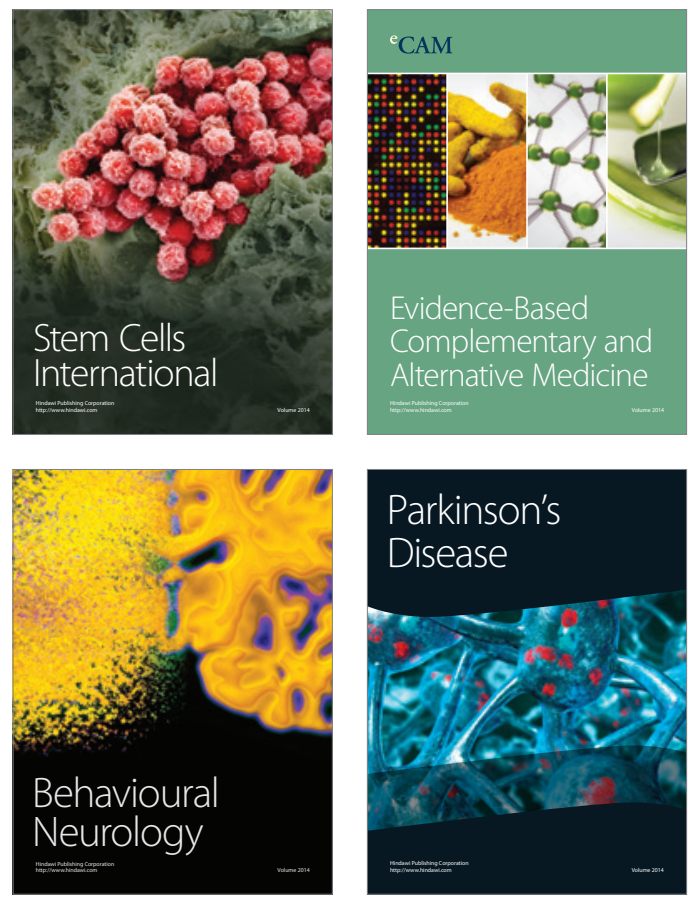
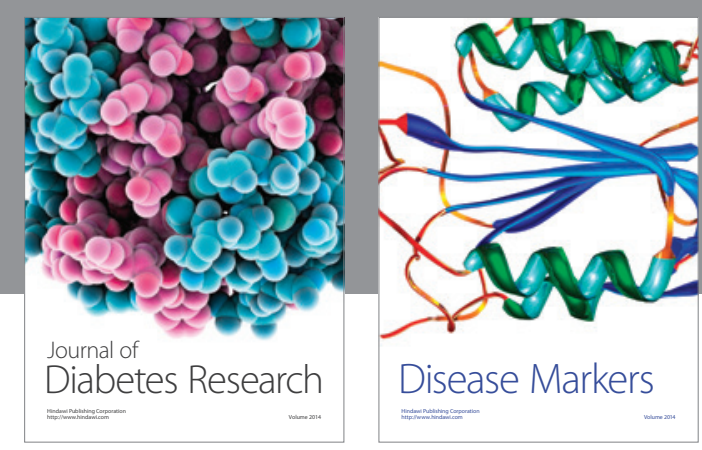

Disease Markers
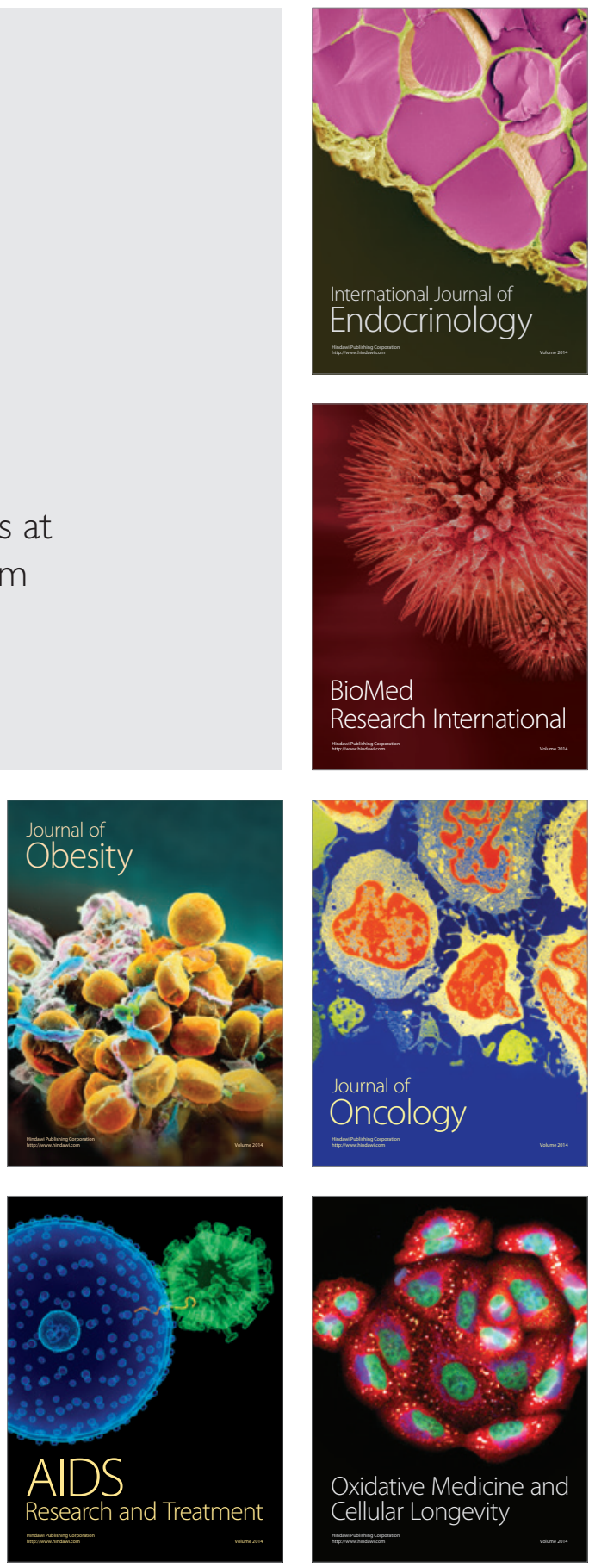